\title{
Office of Biotechnology Activities
}

National Cancer Institute

\section{Source}

National Cancer Institute. Office of Biotechnology Activities. NCI Thesaurus. Code C61428.

An office within the National Institutes of Health that monitors scientific progress in basic and clinical research involving recombinant DNA and human gene transfer, advises federal departments and agencies on ways to minimize the possibility that knowledge and technologies emanating from vitally important biological research will be misused to threaten public health or national security, provides policy advice to the Department of Health and Human Services on the broad array of complex medical, ethical, legal, and social issues raised by the development and use of genetic technologies and Xenotransplantation. 